\title{
A Philosophical Bestiary
}

Joseph Margolis

\section{OpenEdition}

\section{Journals}

Electronic version

URL: http://journals.openedition.org/ejpap/727

DOI: 10.4000/ejpap.727

ISSN: 2036-4091

\section{Publisher}

Associazione Pragma

\section{Electronic reference}

Joseph Margolis, «A Philosophical Bestiary », European Journal of Pragmatism and American Philosophy [Online], IV-2 | 2012, Online since 24 December 2012, connection on 21 April 2019. URL : http:// journals.openedition.org/ejpap/727 ; DOI : 10.4000/ejpap.727

This text was automatically generated on 21 April 2019.

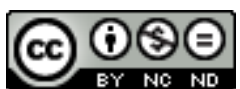

Author retains copyright and grants the European Journal of Pragmatism and American Philosophy right of first publication with the work simultaneously licensed under a Creative Commons AttributionNonCommercial-NoDerivatives 4.0 International License. 


\title{
A Philosophical Bestiary
}

\author{
Joseph Margolis
}

1 When Hilary Putnam asked, “Was Wittgenstein a pragmatist?" he admitted straight out that the title of his lecture was "misleading, for I will [he explained] be talking as much or more about the relation of Wittgenstein's philosophy to Kant's as about its relation to, say, William James's." He meant, he says, that he could have titled it just as aptly, "Was Wittgenstein a Neo-Kantian?"1 Of course. Although the added clue was meant to be as inexplicit as the question, a warning of sorts about an unmarked danger, a piece of induction. The fact is, Putnam viewed Wittgenstein's "later philosophy" as "paralleling certain themes in Pragmatism" and signaled that he regarded the resemblance as being important to the direction (very probably, the redirection) of current philosophy. ${ }^{2} \mathrm{He}$ ventured a hint he knew would be widely construed as favoring a traditional or conservative treatment of the future of pragmatism and analytic philosophy (and philosophy at large) by remarking at once, within his triangulation, his intention "to combat the prevalent idea that Wittgenstein is simply an 'end of philosophy' philosopher." $\mathrm{He}$ draws a similar lesson from his remarks on Kant. He means to restore a proper sense of his own relationship to Wittgenstein and the classic pragmatists - to John Dewey, preeminently - in order to provide (against a skeptic's misreading of philosophy in the large) a corrected sense of how the kinship between Wittgenstein and the pragmatists helps to secure our own bearings under a widening threat.

2 There can be no doubt that, here, Putnam is combating what he regards as Richard Rorty's picture of Wittgenstein - hence, then, Rorty's pragmatism as well. But to concede the complexity of that admission is, as we shall see, to enter into the rollercoaster inquiry of where pragmatism may now be headed. In my reading, twenty years later, that's to conjure not only with Rorty, Putnam, and Wittgenstein - and Kant (and James and Dewey and Peirce, on Putnam's view) - but also with Wilfrid Sellars, Gottlob Frege, Robert Brandom, and (I would add) Huw Price, who have not, until recently, been counted as the nearly indispensible (not entirely reliable) pragmatist players they have become in current disputes about pragmatism's fortunes. I take the inclusion of figures Putnam does not mention to help define an expanding agon that cannot be confined to Putnam's original confrontation with Rorty. Brandom, for instance, is not a Rortyan skeptic, though 
his own 'recovery' of pragmatism is itself a response to Rorty's provocation. The sense of Putnam's question has become more diffuse, but also more compelling.

3 I'm unwilling to say that any of the last group mentioned affords an acceptable instruction as to pragmatism's prospects: I don't think any of them actually does. But the best advice, bearing in mind the sense of Putnam's question, arises from engaging their challenges, just as, close to forty years ago, the best sense of pragmatism's resources arose quite naturally from the minor distraction of that dead end of a dispute between Rorty and Putnam that brought the last decades of the last century to a surprising close without Rorty or Putnam being responsible for any forceful revision of pragmatism's future.

Putnam's question is an important one, though Putnam himself is drawn to an unpromising distraction. Certainly, neither Rorty nor Kant nor James can be expected to adjust our philosophical compass now in any fresh way; and though Wittgenstein remains remarkably rewarding, Putnam's own clue regarding Wittgenstein's innovation is more than coy. Brandom's challenge is finally more important than Rorty's, but it too threatens to be a very large distraction in favor of an entirely subsidiary adjustment - within the boundaries of formal semantics (however notionally applied to natural-language discourse). Nevertheless, I'm convinced that we shall find ourselves on firmer ground, as pragmatists, focused on the movement's best prospects (from here on out), if we can get clear about why it is that the philosophical turn Brandom pursues among his closest discussants is, finally, a deflection from the main topics that should confront us.

The question about Wittgenstein draws us to an important clue that cannot (I surmise) be adequately examined solely in accord with Wittgenstein's own strategies. Ironically, Brandom's misreading of Wittgenstein returns us (quite unintentionally) to a more promising venture: namely, to the reconciliation of pragmatism and naturalism on the strength of new priorities, the defeat of newer versions of deflationism that have replaced the failed energies of Rorty's "postmodern" pragmatism and those of the impossible extremes of twentieth-century scientism, as well as the dawning sense of the primacy of the resources of the human self, which begin to set decisive constraints on the redefinition of a defensible naturalism committed to the actuality of the self's powers. Count all that the barest sketch of a brief in favor of a new beginning - hardly captured by the contest to be examined here. You cannot fail to see that the work of a figure like Brandom is bound to play a not insignificant role in the articulation of a suitable explanation of pragmatism in our time, to match the role Rorty and Putnam played in the final decades of the last century. But I intend no invidious comparisons: the pertinent contests of the two periods are very different indeed.

6 Rorty, of course, packaged Wittgenstein and Dewey together (and Heidegger, let us not forget) as 'postmodern' pragmatists of his own persuasion. All that's gone by now; nevertheless, part of the dismissive intent of Rorty's 'pragmatism' has morphed into the revival of the deflationary and minimalist proposals of more recent, more eccentric, selfstyled pragmatists in pursuit of their own often extreme economies along the lines of certain forms of naturalism (as in the work of the Australian philosopher, Huw Price, actively engaged in debate with Brandom) and, of course, of inferentialism (in Brandom's own vigorous proposals).

7 It's my conviction that, partly because of its remarkable revival, pragmatism is being drawn, separately, into close dialogue with certain temptingly spare forms of analytic philosophy and other temptingly florid forms of settled continental philosophy. On the 
analytic side, it should be clear that it will be useful to revisit with care the question what might now be the best way to integrate the often divisive concerns of pragmatism and naturalism and, as a direct consequence, the unexpected revival of the distinctly remote projects of formal semantics, now somehow reconciled with pragmatism itself. I'm persuaded that these confrontations should serve in shaping a better answer to Putnam's question about Wittgenstein: partly because Wittgenstein (early and late) is so engaging to Fregeans and Deweyans alike, as he is to discussants like myself who are drawn to the need to neutralize the self-impoverishing 'disenchantment' so much in vogue in late scientistic philosophies.

8 Price and Brandom share these themes - as, indeed, did Rorty and Putnam in rather different ways. Brandom strikes me as the natural stalking horse for our present purpose: he is certainly more than Rorty's principal student, undoubtedly the most unorthodox self-styled pragmatist of the movement's recent history, without a doubt the single most visible, skillful proponent of a radically reoriented (still incompletely articulated) 'pragmatism' for our day, engaged with all the themes I've mentioned (and more); and, I should add, author of an unavoidable challenge as to how philosophy might now best proceed. (I press this advice without prejudice as to what may prove to be the ultimate verdict on Brandom's bold gamble: that is, I urge it opportunistically.)

9 I happen to think that Price and Brandom have gone astray in certain decisive ways that need to be addressed and 'corrected' in the interest of ensuring a continually tenable, hopefully up-to-date and adequately informed pragmatism. I take the charge to usher in a decidedly useful way of meeting Putnam's question. It should come to rest in due course in the implicit confrontation between Brandom and Wittgenstein. In any event, that is to be the highlight of my own reading of Putnam's question: because I mean to review the newer challenges of naturalism and deflationism, which, by their own instruction, should bring us to the decisive contest between the 'pragmatism' of the Investigations and that of Between Saying and Doing. I trust it will be clear that the larger purpose of the exercise is to assess pragmatism's best prospects currently, in meeting the gathering challenges of the day.

10 It will take a bit of patience to mark the argument's trail convincingly. (I must give notice here that I will not reach all of my intended targets in this single paper.) The inquiry itself falls very naturally into two parts: the preparatory challenges of naturalism and deflationism, which, apart from inferentialism, are Brandom's principal sources for generating alternative options of genuine interest. In that spirit, the first part of the argument - at least the part being sketched here - makes its contribution without fulfilling the essential promise of the second part - or the third. They'll take their turn in due course. But in widening the scope of Putnam's question the issue demands a freer canvass of the entire sweep of contemporary philosophy.

11 Rorty, I note, is unfailingly explicit in the Introduction to Philosophy and the Mirror of Nature. He takes the "three most important philosophers [and pragmatists] of our century -Wittgenstein, Heidegger, and Dewey - [to have] broke[n] free of the Kantian conception of philosophy as foundational":

The aim of [this] book [Rorty says] is to undermine the reader's confidence in "the mind" as something about which there ought to be a "theory" and which has "foundations," and in "philosophy" as it has been conceived since Kant. ${ }^{4}$

12 Putnam condemns the pragmatism Rorty constructs in his "picture of language speakers as automata, 'as' deeply un-Wittgensteinian." ${ }^{5}$ On that reading, Putnam is entirely 
justified. But I doubt it's an accurate reading of what Rorty says. I must admit, somewhat against Putnam, that I'm persuaded that when Rorty compares discursive 'criteria' with 'programs' and speaks of 'language games' as "governed by what he calls 'algorithms' or 'programs'," he may be signaling, very distantly (and misleadingly), no more than his endorsement of some early version of Brandom's inferentialism (well before the publication of Between Saying and Doing), rather than an endorsement of the apparent automatism Putnam claims to find in Rorty's pertinent texts. Though I thoroughly agree that Rorty offers no compelling case for the 'postmodern' pragmatism of The Mirror of Nature that I've barely sampled; it's also reasonably clear that, in rejecting the Cartesian theory of mind, Rorty does indeed endorse the larger doctrine, to the effect that "the wholehearted behaviorism, naturalism, and physicalism I [Rorty] have been commending [...] help us avoid the self-deception of thinking that we possess a deep, hidden, metaphysically significant nature which makes us 'irreducibly' different from inkwells or atoms. ${ }^{16}$ Imagine!

13 I say this cannot count as a fresh strain of pragmatism, if it ever did. Which, of course, would require a proper grounding if we were tempted to impose new constraints on pragmatism, naturalism, realism, deflationism, the relationship between semantic analyses and metaphysics, and the like. At the very least, then, against Rorty; it may be entirely reasonable to support both a 'folk' account of the self's career and whatever in the way of the leanest possible materialism the physical sciences may be deemed able to produce. In that event, such 'pictures' may be said to 'model' rather than to 'map' reality. I see in this a perfectly plausible warning against the excessive claims of a deflationary naturalism (Rorty's and Price's, both). There's a blind spot in Rorty's verdict that will surface in a new guise (much later), in Brandom's formalist rendering of inferentialism.

Rorty has a penchant for introducing preposterous specimens of what otherwise appear to be entirely valid forms of philosophical hypothesis, and then dismissing at a stroke the entire encompassing enterprise as impossible to redeem. Where's the argument? None of Rorty's 'most important philosophers' follows him in going over the philosophical cliff. But you must see that, increasingly, we are being threatened by a glut of indefensible or unrewarding pragmatisms.'

I venture to say, in the way of a preliminary caution, that pragmatism acknowledges (i) the robust functionality, the realist status, of what, unproblematically, we call the human self or person (subject or agent), without insisting that the self must be construed as a determinate 'substance' of this or that kind or as possessing an essential nature, or anything of the sort. (I take this to be close to Dewey's view, in Experience and Nature.) There may indeed be strongly 'deflationary' views of the functioning of the self somewhat akin to the sense in which there are promising deflationary accounts of 'truth' - that cannot be ignored. But as matters now stand (and for the forseeable future), it makes no sense to speak of the achievements of the sciences without admitting some 'strong' sense of truth on which an admittedly subordinate deflationary proposal may afford a useful economy. In much the same sense, I argue that there can be no achievement of the kind we name "science" unless there are also actual agents of inquiry who can be credited with the feats that need to be explained. I should say at once that I mean to return to the improbably strategic importance of the analysis of truth to the future prospects of pragmatism - and the whole of the Eurocentric tradition. The point of the linkage, I dare say, is not yet clear. Let me suggest, for the moment, that the entire 
inquiry centers on the conceptual relationship between pragmatism and naturalism and what that contested topic brings into view.

To return to the tally I've just begun, the upshot of item (i) at once yields, as item (ii), the additional thought that realism (in the pragmatist sense) is bound to be constructivist but not subjectivist (say, in the classic empiricist or Kantian - 'idealist' - manner), 'pluralist' (as it is now often said to be, to avoid pretensions of privilege of any sort); hence, indissolubly linked to one or another acceptably conjectured (post-Kantian) 'Idealist' picture of the real world ('Idealist' with a capital 'I': meaning that it is not at all a merely psychological doctrine), which (in the manner of Peirce or Cassirer or, with charity, Hegel) is what I mean by an 'objective' constructivism that avoids all claims of actually constructing the natural world that we say our science knows. ${ }^{7}$

If so, then (I dare continue), (iii) pragmatism is bound to treat all distinctions between the 'subject-ive' and the 'object-ive,' pertinent to the resolution of standard epistemological and metaphysical questions (of the sort Rorty rejects unconditionally), as matters entirely internal to one or another realist (or realist/Idealist) space of inquiry, indissolubly posited in the sense just broached in item (ii) of the tally that's now unfolding. (I expect you realize that my tally is entirely programmatic.) All that I can say, for the moment, in its favor is, as I've hinted, that the salient weaknesses of the so-called "pragmatist" ventures of figures like Brandom, Price, and Sellars inadvertently instruct us in the need to fashion a more robust alternative to collect pragmatism's best prospects.

18 I now add item (iv) to our tally, namely, that in keeping with pragmatism's avoidance of all presumptions of privilege and contrived or arbitrary disjunctions that might otherwise yield unearned (and unwanted) advantages in resolving cognitive questions, all valid attributions of a cognitively qualified sort are, paradigmatically (or, if preferred, derivatively), ascribed to the nature and agency of functionally apt selves; that is, that, on the thesis that the analysis of language (or meaning) and the analysis of the world we claim to know are indissolubly intertwined - the known world being 'enlanguaged' and natural language, 'enworlded' - the analysis of language, world, and knowledge is insuperably conjectural, penetrated by human interests, holistically indissoluble and determinably realist in its outlook, in accord once again with item (ii). Coordinately, I think we must also postulate, as item (v), the idea that, qua agent, the self is - wherever speaking, thinking, acting, reflecting, and the like are affirmed - the nominal site of all such acknowledged powers, holistically engaged, uniquely emergent under conditions of biological and cultural evolution and enlanguaged Bildung, capable (in maturity) of being reflexively experienced (though not sensorily), entitled to realist standing in whatever respect and degree is accorded the "things" of the world we deem accessible to the sciences and practical inquiry.

19 I dare venture two further premises easily accepted by any viable, reasonably standard form of pragmatism: (vi) that the career of a living self is itself history or a history, or historied; that is, selves are reflexively aware that their conceptual, perceptual, affective, agentive, and related powers are informed and affected by historical changes as a result of having mastered (internalized) the language and culture of the society in which they first emerge and subsequently live; and (vii) that the description and explanation of all the powers of the self and the processes and attributes of the world the self inhabits, comes to know, manipulates, understands, or affects, may, it is supposed, be cast entirely in naturalistic terms, though any viable naturalism must, accordingly, accommodate whatever among the self's first-personal powers prove to be resistant to any dismissive 
form of deflation or reduction or elimination. I'm touching here on some of the dawning contests on which the fortunes of pragmatism and the whole of Western philosophy depend: in particular, those that mark the importance of the distinctive (but not especially orderly) confrontation with figures like Brandom, Price, Sellars, Rorty, and Wittgenstein.

Once you have a schema of this scope and plausibility in hand, you see at once how easy it is to detect deflections from, deformations and abandonments of, presumptions beyond, the modest demands of classic pragmatism. So, for example, the daring of Rorty's 'postmodern' pragmatism cannot possibly be an admissible form of pragmatism if we yield in the direction of the tally I've just contrived. Similarly but for very different reasons, everything remotely in accord with Kant's transcendentalism (but not the 'transcendental' question itself) cannot possibly pass muster. But then, Putnam's 'internal realism' - which Putnam himself acknowledges founders on its adopting an empiricist form of representationalism (very possibly misled by James) - cannot be defended (as a viable form of pragmatism) any more than the thesis that worried Kant in his famous letter to Marcus Herz. ${ }^{8}$ Nevertheless, 'representationalism' in any benignly Hegelianized ('presuppositionless') form of phenomenological 'presentationalism' (as in Peirce's variant) may actually be needed to offset, convincingly, every illicit form of perceptual or cognate privilege.

21 It may not seem so, but I am indeed responding to Putnam's question. I take Putnam to be asking: "If Rorty calls himself a pragmatist, then can we reasonably call Wittgenstein a pragmatist?" The question has to do with pragmatism's future. So that now that Brandom has actually formulated his picture of the pragmatist promise of his own inferentialism what he calls 'analytic pragmatism' - we begin to recognize an entirely fresh attempt to subsume or adjust pragmatism's classic intuitions under auspices that threaten to drown out or effectively marginalize what are pragmatism's best insights vis-à-vis the most important and likeliest contests of our day.

In this sense, the answer to Putnam's question is, quite simply, No! Wittgenstein is not a pragmatist in any instructive sense; Rorty is, finally, a pragmatist only in the comic sense in which any large doctrine may be completely disorganized by turning its own commitments against its 'truer self'; and Brandom may be counted a pragmatist chiefly, I would say, on the basis of equivocating between the 'pragmatic' commitments of any standard version of philosophical pragmatism and the so-called "pragmatic" features of the semantic analysis of discourse directed at making explicit the inferential implications of what we do by way of verbal and nonverbal behavior, that may be expressed (functionally or 'logically') in terms of what we 'say' (or may say) 'expresses' the implicit inferential import of what we actually 'do'; and partly on the strength of Brandom's affection for the 'pragmatism' of figures as diverse as Rorty, Dewey, Sellars, Frege, Wittgenstein, Davidson, Heidegger and others labeled by Rorty (at one time or another) as pragmatists. The moniker hardly matters, but the confusion that results is hardly helpful. Pragmatism faces a remarkably open opportunity to strengthen its various undertakings in our own time. I would hate to see it squandered in the newly refurbished quarrels now intriguingly resurrected from the past.

Here, if I understand Brandom correctly - I'm not sure I do understand him, I'm not sure Brandom's introductory remarks about the inferentialist program he introduces, in Between Saying and Doing, are entirely transparent - I would be willing to say that we could, without the least disadvantage, construe our pragmatist reading of the functional 
use of any so-called 'target' vocabulary (in terms of any so-called 'base' vocabulary favored for the inferentialist game) as either 'representational' or 'expressive.' We would, of course, have to admit some sort of benign 'privilege' at least two foci in either sort of account: in the sense, first, that something meaningful would have had to be 'given' (presuppositionlessly) in the target vocabulary, which we would wish to preserve in our explication; and, second, that the explication itself would, thus far at least, adequately preserve the 'meaning' thus given. Alternatively put, any deflationary or reductionist or similar search for would-be 'semantic' economies would have to be independently defended. ${ }^{9}$ There is no a priori reason why a representational theory of language or an epistemologically qualified theory of truth must be unacceptable within the terms of the leanest form of naturalism adequate to pragmatism's needs. But I don't deny that that's a quarrelsome claim.

Brandom introduces his own undertaking as follows:

What I want to call the "classical project of analysis" [formal semantics, or, more narrowly, what Brandom names "semantic logicism"] [...] aims to exhibit the meanings expressed by various target vocabularies as intelligible by means of the logical elaboration of the meanings expressed by base vocabularies thought to be privileged in some important respects - epistemological, ontological, or semantic relative to these others.

This Brandom calls 'the core program'; the famous 'extension' he wishes to add (to round matters out) - that is, the rules of inferentialism - comes from 'the pragmatist challenge' (he says) he associates chiefly (always by way of Wilfrid Sellars's very different labors) with Wittgenstein's distinction between 'meaning' and 'use,' which Brandom regards as the nerve of 'Wittgensteinian pragmatism. ${ }^{10}$ So he means to answer Putnam's question as well!

You see, of course, if you allow the liberty, that it no longer matters whether we prefer to speak in the idiom of 'representation' or that of 'expression' (which both Price and Brandom worry in terms of deflationist preferences of different degrees of daring): we can invoke either notion at any point in the same exercise (or both together); each (we suppose) addresses the substantive aspect of discourse that we would not want any strictly deflationary or deflationary naturalist maneuver to displace. Beyond all that, which must be examined more carefully, I see no reason to disallow Brandom's attempt to provide 'a complete account of semantics': the only questions that arise ask (benignly), Is the program viable? Is it robust enough to be worth pursuing? Are there restricting or disabling complications that have not yet been acknowledged? Does it qualify as an enlargement of pragmatism's own program? Has Brandom read Wittgenstein correctly? Sellars? Dewey? Frege? Or, indeed, Peirce? ${ }^{11}$ (We have only to resist the fatal conviction that deflationism is an autonomous semantic discipline that overrides any "oldfashioned" metaphysics). Deflationism, I say, is always an encumbered and dependent philosophical strategy: it cannot completely disjoin semantic analysis and "metaphysics." 12

Curiously, Brandom reports Rorty's actual response to drafts of his Locke lectures (now collected as Between Saying and Doing), which reads as follows: "Why in the world would you want to extend the death throes of analytic philosophy by another decade or two?"13 Rorty saw at once, you realize, the retrograde possibilities of Brandom's innovation. Imagine! Given Brandom's response, it's perfectly clear that the answer is in good part a matter of philosophical taste. Nevertheless, Brandom's answer does begin to explain the 
sense in which his venture is much more traditional and conservative than one might have supposed -possibly even regressive when compared with Wittgenstein, Dewey, Rorty, Putnam, and Sellars - despite his affirming his openness to 'epistemological, ontological, and semantic' issues and his willingness to address the resources of 'folk' vocabularies. Rorty's reaction is rather more puzzling, because Rorty surely knew what Brandom was up to. (I can only think that Rorty's remark was meant to be reported as a comic putdown.)

Huw Price, a rising Australian philosopher and an ally (and opponent) of Brandom's, actually suggests that Brandom may be a 'counter-revolutionary' analyst or pragmatist or 'analytic pragmatist. ${ }^{14}$ The point at stake is that Brandom cannot be easily pinned down as to where, precisely, he stands with respect to the conceptual issues his own inferentialism poses regarding topics like empiricism, naturalism (especially naturalism), deflationism, traditional metaphysics, realism, minimalisms of various kinds, defensible ways of speaking of subjects and objects, the relationship between epistemology, ontology, and semantics and the like. It's not clear at all that Brandom addresses theses issues adequately (or as a committed pragmatist) - as when he lays out the largely formal schema of the inferentialist program sketched in Between Saying and Doing. That is, from the side of naturalism and realism, for instance, or from the side of semantic analysis informed by same. There's the question we must pursue if we are to answer Putnam's opening question perspicuously: to catch a glimpse of what new philosophical options may be in the offing. Brandom is surprisingly guarded about committing himself 'metaphysically,' though I would not say that he equivocates there. He hasn't fully resolved the question in his own mind!

In fact, the topics just mentioned, which are among the principal topics of the day, seem overly familiar - as of course they are. But the novelty persists: What, finally, should we regard as the most tenable account of the relationship between pragmatism and naturalism? Through the whole of the analytic tradition of the last century, the favored answer has been this: that pragmatism must yield to the scientistic (or reductive) economies of naturalism. I venture to say that, now, it makes more sense to hold that naturalism must concede the prior force and standing of the essential requirements of pragmatism (if, that is, something close to the pragmatist themes I've tallied a short while ago can be reasonably defended). Naturalism is a variable doctrine subaltern to our adherence to some more fundamental claim: pragmatist or reductionist, for example. I regard the change as a tribute to the rising importance of the theory of the self. Price, I may say, takes an uncertain view of the primacy of the human subject: he clearly rejects the 'popular' naturalistic thesis that holds that, in relevant contexts, "philosophy" must yield to 'science. ${ }^{15}$ But I cannot see how he finally eludes its grasp; he does not explain the proper scope of deflationism, which cannot fail to be a subaltern strategy. In a way, I welcome Price's insistence (his 'Priority Thesis') to the effect that "subject naturalism is theoretically prior to object naturalism" (which stalemates reductionism, if I read it aright); but that does not quite settle the relationship between naturalism and pragmatism. There must be suitable (pragmatist) constraints on deflationism, if the Thesis is to be read, finally, along pragmatist lines.

In effect, the required shift now means our being prepared to rebut any and all impoverishing deflationary economies with regard to metaphysics and epistemology. That is, if we correctly perceive that naturalism has no privileged standing. Indeed, neither has pragmatism. Nevertheless, in different ways, the admission is compromised 
by both Price and Brandom. Brandom and Price have, then, begun to occupy the eccentric successor roles of the opposition Putnam and Rorty originally shared at the end of the twentieth century. Both of the new contenders are clearly caught up with a nostalgia for the scientistic: Price (influenced by Simon Blackburn's 'quasi-realism') perhaps more daringly than Brandom. My own guess has it that the freshest and most engaging moments of the developing contest, which ranges far beyond any merely local skirmish, will come to rest among the pros and cons (once again) of deflationary and counterdeflationary treatments of truth and disputes regarding representationalism and realism and the strategies of metaphilosophy.

31 Now, what am I actually offering in the way of a guess at pragmatism's changing prospects? I'm persuaded that we're approaching a new agon obliquely. The center of gravity will be the consolidation of a simplified, greatly strengthened. An enlarged pragmatism and the leanest possible form of naturalism we can defend. The current forays that command attention are all at least partially retrograde. The best of these favors semantic deflationisms of a variably reductionist or eliminativist or merely extensionalist cast: most wildly in Rorty; traditionally and rather one-sidedly (thus far), in Brandom; and possibly in the riskiest way, in the deflationary sense, in Price. I don't believe it's the power of conceptual invention that's decisive; it's the provocation of largely neglected or incompletely examined puzzles suddenly remembered because they have been revived in a more confrontational and more insistent form than is usual.

What I surmise has happened is that a new tension is beginning to make itself felt regarding the analysis of the human self or subject: that's to say, regarding the most essential topic of the entire movement we know as pragmatism. On the one hand, the conjunction of deflationism (as with the semantics of truth and meaning) and the continuing attraction of the supposed primacy and autonomy of semantic analysis (with respect to marginalizing 'traditional' metaphysics and epistemology) threaten to recover reductive and eliminativist intentions by semantically and informationally contrived strategies; and, on the other hand, conceptual economies regarding the functionality of the self (in science and morality, or in accord with the 'natural artifactuality' of language and enlanguaged and encultured human life) are beginning to require a fresh assessment of the sense in which the self remains a thoroughly natural kind of being. You realize, therefore, that the more promising, newer constraints cut against the older scientistic wave of naturalism - a fortiori, against the scientistic strains of deflationism.

I admit I favor the anti-scientistic turn, particularly the enrichment of the theory of the self, where it favors joining Hegelian and Darwinian themes. But these have not yet been picked up with conviction by more recent inquiries -which, to my thinking, confirms the continuing attraction of regressive impulses among analysts, pragmatists, and naturalists alike. For similar reasons, there's little that's arresting in the way of novel treatments of social, cultural, historical, biological, paleontological, evolutionary, normative, communicative, informational phenomena among naturalists and pragmatists. My intuition is that the recovery of a robust conception of the self will proceed along artifactualist and constructivist lines; otherwise, insistence on a merely functionalist treatment of the self is likely to retreat to the effective autonomy of semantic economies, the minor exercise of testing the tolerable limits of a dependent deflationism, and the inchoate reduction (or elimination) of the cultural and linguistic world in biochemical and neurophysiological terms. I offer in evidence the amusing but otherwise impoverished conclusion steadfastly championed by Daniel Dennett. ${ }^{16}$ 
The importance of Huw Price's contribution to the growing dispute regarding pragmatism's future lies with his rather daring sense of naturalism's liens on pragmatism's options. For one thing, he's suspicious of philosophy's 'old-fashioned' metaphysics and epistemology; he favors the authority and competence of 'science' (in what degree, is not entirely clear) to determine all pertinent facts regarding what may be found in the world. As he says, "there is no framework-independent [extra-linguistic] stance for metaphysics." ${ }^{17}$ I agree. (But, surely, one must concede the inverse with regard to semantic analyses as well.) Price also supports the following quite ingenious thesis, which he calls 'functional pluralism,' the conception of which (if it entails no prejudice to the standing of any substantive claim) I find entirely congenial:

A functional pluralist accepts that moral, modal, and meaning utterances are descriptive, fact-stating, truth-apt, cognitive, belief-expressing, or whatever - and full-bloodedly so, not merely in some ersatz or "quasi" sense. Nevertheless, the pluralist insists that these descriptive utterances are functionally distinct from scientific descriptions of the natural world; they do a different job in language. They are descriptive, but their job is not to describe what science describes. ${ }^{18}$

Pluralist strategies may be reconciled with naturalism, therefore, if we possess arguments sufficient to make the case. For instance, I willingly concede that there are no 'moral norms' to be found in the world as 'actual' or 'real' or 'existent' in any respect in which human persons are found in the world. But, for one thing, I reserve the right of any philosopher to attempt to make the contrary case. For a second, I would not deny that humans have indeed constructed plausible forms of moral discourse that answer to their interests and are capable of sustaining rational dispute and rational commitment firm enough to vindicate their (that is, our) practice of speaking of moral truths and moral facts. For a third, I would not support a similar claim against the actuality of words and sentences or persons or families or artworks or money or political states or the like. And, for a fourth, I see no plausible way of precluding the question of the naturalist standing of selves across science and morality (or similar categorical demarcations).

Given such constraints, I would argue that there is no disjunctive line to be drawn between science and philosophy (or metaphysics), or indeed between science and nonscience; and that, as a consequence, there are no compelling arguments to be had in favor of the 'primacy of science' over (say) philosophy or art criticism or history - or, any privileged disjunction between semantic analysis and metaphysics. Hence, I take the following characterization (by Price) of the "functional pluralist's" position to be seriously misguided or at least indefensible:

functional pluralists [...] speak from within the scientific framework, but about other frameworks. This gives the scientific framework a kind of perspectival primacy. Our viewpoint is internal to science, but external to morality, for example. It is a viewpoint which allows us to refer directly to the objects and properties countenanced by science, but not to the objects countenanced by the moral stance.

This spells out (very briefly) what Price means by his subscribing to what he names 'the Carnap Thesis' (regarding 'internal' and 'external' questions). ${ }^{19}$ But I cannot see that the 'functional pluralist's' demarcation policy has any plausible payoff regarding the relationship between pragmatism, naturalism, and deflationism, unless it's to debar us from posing essential questions. The philosophical standing of the self or person is simply 
too important to be settled by verbal devices: the self belongs, if it belongs anywhere, to science and morality alike. (If so, then the 'Priority Thesis' is not well formed).

It's on such grounds that Price comes to favor potentially privileged, often quite extreme deflationary (or minimalist) strategies: for example, what he calls the 'Priority Thesis,' according to which (broadly conceived), "if the claims and ambitions of philosophy conflict with what science tells us about ourselves [and, it would seem, about the world that science knows] then philosophy needs to give way." Nevertheless, Price also notes that science "cannot turn its spotlight on the language of science itself." ${ }^{20}$ So there are unresolved aporiai at the very heart of Price's naturalism; hence, grounds for serious objections affecting not merely his own proposals but all efforts to ensure the objective standing of deflationary and minimalist economies ranging over all 'metaphysical,' 'epistemological,' and 'semantic' disputes. As Price concedes: 'the contribution on our side [regarding whatever counts as an objective picture of the real world] never goes to zero." 21

I cannot see how these views can be coherently reconciled. But then, you glimpse, here, the sense in which arguments (by Brandom and Price) said to be hospitable to pragmatism's future prospects instruct us (unwittingly) about what is closer to pragmatism's true fortunes among the contests that are just now surfacing along potentially productive lines. ${ }^{22}$

40 I would say Brandom's intuition was more promising than Price's (but noticeably less explicit), just where Price takes Brandom to be equivocating or to be actually inconsistent - in the spirit of Price's provocatively deflationist option (barely bruited here). Nevertheless, Brandom's own attraction to deflationism (or what he offers as its 'prosentential' analogue ${ }^{23}$ all but wipes out the gain he nearly secures. Both Price and Brandom seek roundabout formulations of what, without prejudice (or 'metaphysical' intent), we may as well call seeking truth - though in such a way that both Price and Brandom manage to preclude the actual use of 'true' as an ascribable predicate that serves (in Brandom's deprecating characterization) as explanatory 'guarantor of the success of our practical endeavors' ${ }^{24}$ - what I've dubbed 'seeking truth' solely to keep our disputed goal in view. The only reliable objection to Brandom's deflationary charge (but the objection does indeed count) is that 'true' fills predicative roles that are not committed in any way to cognitive privilege (or, for that matter, to ordinary 'explanatory' tasks). I am prepared to argue that every strong deflationary paraphrase of 'true' omits what we cannot afford to leave out, or circularly implicates what we claim to have dismissed, or is tautologically uninstructive with regard to the elusive consideration in question. I mean, of course, the realist import of the truth predicate. Recall that, on my view, philosophical semantics is metaphysics in another guise. If I'm right about this, then even the most effective and compelling deflationary treatment of "truth - surely, the treatment Paul Horwich accords it - signals its own ineluctable defect.

41 We've arrived, then, at an essential contrast, a place at which to begin to decide the respective fate and fortune of the deflationary/anti-deflationary treatments of 'truth,' 'represenationality,' 'reference,' 'evidence,' 'knowledge,' 'reality,' and the like, essential (as I see matters) to deciding the right or best (or, perhaps better, 'second-best') way to reconcile pragmatism and naturalism in our time. I take 'truth' to be the exemplary case, and Price and Brandom to have failed us in the pragmatist's quest. Effectively, there is a function of the predicate 'true' that is inseparable from the epistemic function of 'fact' or 
'confirmed fact' (or the like), which deflationists cannot convincingly account for or explain away semantically.

I can spare very little space here to specify the force of what I take to be the pragmatist complaint, perhaps most clearly anticipated in Peirce's paper, "The Fixation of Belief" but surely implicit in the classic pragmatists' treatment of 'truth' (no matter how tortured). I find the nerve of the quarrel adumbrated, unintentionally, in Brandom's chapter, titled "Why Truth is Not Important in Philosophy." Consider, for instance, the following lines:

I've said that my claim that truth is not important in philosophy should not be understood as denying the importance of truthfulness, epistemic conscientiousness, or assessments of knowledge. But I've also said that in each of these cases, though we may if we like talk about the phenomena in question in terms of truth, we need not do so, and lose nothing essential if we do not. ${ }^{25}$

This sounds reasonable but it is not: it falls far short of what a full-blooded pragmatism would (rightly) require. What is the point of separating 'truth' and 'epistemic conscientiousness' if truth is treated in the strongest deflationary way?

There remains a still-unanswered objection: namely, that a would-be essential use or function of true' (which Brandom and Price intend to displace or deflate in somewhat different ways) cannot be secured by any merely psychological or semantic element (unless suitably linked to what is epistemologically still missing); hence, that the function needed cannot be derived from any would-be prior inferential linkage between what we say and what we do (according to Brandom's strategy). I'm convinced that this single challenge stalemates every merely deflationary account of 'truth' - hence, also, every inferentialist program (of Brandom's sort) that claims to be full-service (including Brandom's own variant).

I'm certain we can do better in reconciling pragmatism and naturalism, because there are a good many 'methodologically temperate' factual discoveries about the advent of language, the functionalities of the emergent self, the nature of enlanguaged cultures (drawn in part from post-Darwinian paleoanthropology) that are in noticeable accord with the pragmatist's essential commitments (tallied earlier) - where pragmatism is clearly not in accord with scientism - commitments Price tends to discount or 'deflate' if he can, preferring scientism's seemingly more robust facts, all the while he presents himself as a pragmatist (as in his seemingly robust 'Priority Thesis').

Price's executive commitment insists that the analysis of 'representationalism' and (say) 'truth' should be conducted from a vantage that "remain[s] resolutely on the 'word' side of the word/world divide." ${ }^{26}$ (A policy meant to hold for pragmatists and naturalists alike - but is plainly nowhere secured.) Price is either arbitrary here or in tow to his own unguarded metaphysics. I find the worry confirmed, however innocently, in Price's socalled 'Priority Thesis,' which I've mentioned in passing and which is best read as a deflationist's version of pragmatism:

Subject naturalism [Price says] is theoretically prior to object naturalism, because the latter depends on validation from a subject naturalist perspective. ${ }^{27}$

Certainly, this much of Price's view may seem to accord with pragmatism's priorities. But the formulation is hardly perspicuous. We are not told how to distinguish between the claims of science and the claims of philosophy, and we are not told how the argumentative resources of the 'two' sorts of naturalism are to be shared or divided - or indeed what 'priority' now means. We are hardly told what 'subjects' and 'objects' are. 
By 'object naturalism' Price intends the doctrine, ontological or/and epistemological, that holds that 'all there is the world studied by science' or/and that 'all genuine knowledge is scientific knowledge.' By 'subject naturalism,' however, he means, eccentrically, that "science tells us that we humans are natural creatures, and if the claims of and ambitions of philosophy conflict with this view, then philosophy needs to give way." But surely that means (may at least be construed as meaning) that 'subject naturalism' is itself subsumed under the umbrella of 'object naturalism' (or is entitled to claim evidentiery resources that are not yet spelled out), which sets the stage for an extensive deflationism - $a$ fortiori, for a deflationary version of pragmatism itself. It's also possible that Price is committed to inconsistent readings of his 'subject naturalism': on the one hand, subject naturalism is addressed to a sub-topic of object naturalism and is subject, therefore, to the latter's priorities: on the other hand, the whole of object naturalism presupposes the validative 'priority' of subject naturalism, so subject naturalism is characterized in some privileged way. ${ }^{28}$ Beyond all that, Price explicitly says that he is committed to 'naturalism without representationalism'29 - which is, of course, the first salvo of a very strong deflationism that cannot fail to undermine the 'normal' priorities of a pragmatist's reading of the 'Priority Thesis.' (Representationalism, like truth, is a profoundly equivocal notion, as Kant discovered.)

The clue I spy is naive enough. For one thing, I agree with what Price calls the 'insubstantialist' account of truth: namely, 'that truth itself plays no significant causalexplanatory role' of its own..$^{30}$ For a second, I have no doubt that what we mean by 'truth' (as well as what we mean by 'knowledge' and 'reality'), within the context of any body of science, cannot be simply discovered, must be a reasoned construction of some kind relative to human interests; hence, that to hold that semantic analysis is inseparable from metaphysics (and epistemology) produces no paradox at all. Nevertheless, there is a third consideration to conjure with: namely, that truth concerns a distinctive kind of relationship between (what is often called) the 'assertoric' use of language and whatever belongs among the 'things' of the world that assertion and action engage (as by 'saying and doing') - a relationship that, invoking our understanding of the nature of human selves and their interests, supports an all but indefeasible, generic, realist conviction, without indefeasible criteria or conceptions of any sort regarding meaning, knowledge, reality, or the like.

In this sense, I would not say, with Price, that truth is merely 'insubstantialist': it does answer to our 'substantialist' sense of the actuality of our world; the uniqueness of our discursive and reflexive powers ubiquitously involved in all our engagements with the world; and, most important, our practical or effective inability (in what may be rightly qualified as 'pragmatic' - in Peirce's and Dewey's convergent picture of the continuum of the animal and the human) to 'doubt' or deny the realist import of our involvement with the world. In short, for all our philosophical cleverness, we cannot (in the pragmatist sense) shake free of our spontaneous, more or less ubiquitous commitment to the realist cast of assertoric 'success,' which, of course, is hardly hostage to any particular truthclaim. Furthermore, although there are, admittedly, important parallels between the functions of cognitive and moral norms and even between 'realist' beliefs regarding truth and (may I say) beliefs of moral 'correctness,' the insuperable 'persuasion' of the first cannot be matched by that of the second.

In this sense, 'truth' answers primordially to a presumptive realist relationship between assertion and world, whereas moral 'assertion' at its most fundamental cannot claim to 
rest on a similarly irresistible presumption. I take that to be a very strong abductive intuition, impossible to confirm decisively.

Price may have been too quick, then, in denying Brandom a better option against his own sort of minimalism. He cites Brandom's words against Brandom's unguarded tendency toward metaphysical 'inflation,' hence, toward an old-fashioned, outmoded way of doing metaphysics; that is, he signals that Brandom is equivocally attracted to representationalism all the while he (Brandom) assures us that he means to address such matters 'semantically.' But I see no inconsistency there, only a small philosophical confusion.

In a perfectly straightforward sense, 'metaphysics' and 'epistemology' cannot be philosophically separated from 'semantic analysis', or it from them. Semantics is metaphysics by another name (pace Carnap, Quine, Michael Dummett, and an army of others): we need a test of sorts (however provisional or ad hoc) by which to settle the pragmatist status of figures like Brandom, Sellars, Frege, Quine, Carnap, Rorty, Putnam, and (now) Price, and perhaps Wittgenstein; and the test we need cannot apply disjunctively to human 'subjects' and physical 'objects' (or to what Price speaks of as 'subject naturalism' and 'object naturalism') - or to sorting the 'purely verbal' function of 'semantic' distinctions from those that are (somehow) metaphysically freighted. There's the nerve of the emerging agon involving pragmatism and naturalism. The unlikelihood of vindicating any such disjunction is classic pragmatism's ace - whatever quarrels may appear to arise regarding truth, validation, knowledge, meaning, or reality! Abduction (in Peirce's best sense) takes a distinctly holist and realist cast that corresponds very neatly to what Wittgenstein calls 'a form of life.'

I'll add a small bit more regarding Paul Horwich's exemplary attempt to secure the sparest possible (most unyielding) form of deflationism that can be found (what Horwich calls 'minimalism'), to assure you that the objection I've advanced applies to Horwich's thesis as readily as to Price's and Brandom's alternatives. The following is the leanest version of deflationary minimalism that I'm familiar with:

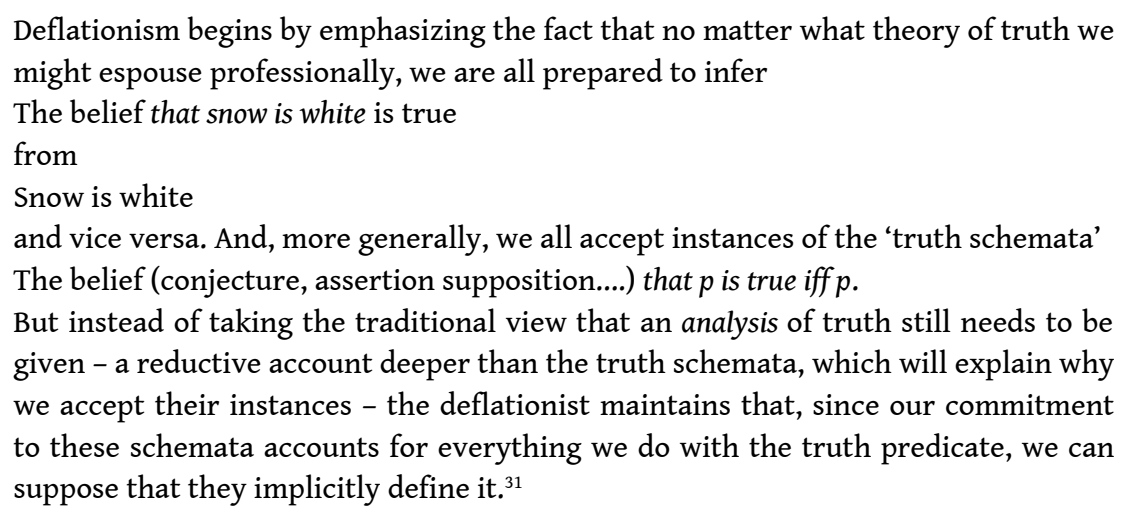

55 I take this to be irreconcilable with pragmatism, simply because the use of 'true' is inseparable from whatever counts as the outcome of successful inquiries regarding worldly things viewed in terms of human interests. Speaking rather unguardedly, the essential issue is either not the analysis or definition of the 'truth predicate' (along the lines of the 'truth schemata' given) or it concerns the relationship between the use of the truth predicate (in something like the first sense) and the usual accounts of metaphysical and epistemological questions having to do with what we regard as an actual body of knowledge (suitably validated) that, for that reason, counts as a proper part of the 
analysis (of the use) of the predicate 'true.' In this sense, though I regret having to say so, Horwich is finally evasive. leave us all at loose ends. Well, not completely. Let me mollify you some. What I've done thus far is provide a set of considerations in terms of which Putnam's question should be met (and would be met effectively) by staging a confrontation between Brandom and Wittgenstein rather than by featuring a reminder of Rorty's extravagant (and improbable) readingof Wittgenstein, or a tepid picture of Wittgenstein's convergence in the direction of certain of Kant's concessions. (This is, in fact, the nerve of what is to be the second part of the larger inquiry of which the first part is now before you: the fundamental disagreement between Brandom and Wittgenstein regarding a matter that supposedly affects the pragmatist standing of each.) The decisive reason, I've suggested, is simply that it is indeed Brandom who has effectively challenged every conventional form of pragmatism and analytic philosophy to change its orientation along the lines of what Brandom calls 'analytic pragmatism.' Brandom has made an arresting case for a new constellation of convergences involving strenuous options drawn especially from the different, sometimes overlapping interests of naturalism, deflationism, and inferentialism. ${ }^{32}$

That is, I suggest we try to answer Putnam's question by looking to the most salient topics of our imminent future. I have no doubt that the central agon will at least include, certainly for a not insignificant season, the pragmatist and analytic critique of Brandom's inferentialism. (The second part of this essay centers on what I take to be Brandom's profound misreading [or misunderstanding] of Wittgenstein's 'meaning'/'use' distinction, on the strength of which Brandom claims to base the pragmatism of his own undertaking.) Nevertheless, I think it may well be that the general suggestion I've been exploring here is, finally, more important than the specific confrontation I recommend. If that proved true, it would yield a striking, however distant, analogue of the original stalemate between Rorty and Putnam (which went nowhere philosophically and yet revitalized the academy's interest in pragmatism in the most remarkable way). In any event, the original question only seems to elude us as its implications become more evident.

According to Putnam, Wittgenstein and the pragmatists converge. I grant the point -and move on to a greener comparison. I suggest we consider instead the respect in which, misreading Wittgenstein, Brandom utterly fails to bring his project into accord with the most minimal considerations essential to pragmatism. The trouble is, the argument leading to Brandom's conclusion should accord with the findings I've now laid out regarding the resources of naturalism and deflationism; here, standard arguments examined in terms of specimens drawn from Price and Horwich prove to be very difficult to make convincing. Furthermore, the actual argument involving the comparison between Brandom and Wittgenstein has proved to be about as long as the preliminary argument now before you. In fact, it requires its own stage-setting, which I couldn't possibly have included here. So I'm obliged to stop and signal (all too briefly) just how the rest of the argument should play out and what it should entail. I can only hope, therefore, that you find this part of it intriguing enough to wait to see how its sequel plays out.

European Journal of Pragmatism and American Philosophy, IV-2 | 2012 
Reasonable cautions against the excesses of deflationism and those of scientisticallyminded naturalisms do not need to wait for the second part of the argument. They are reasonably free-standing and convincingly concluded here; and, of course, they count straightforwardly in favor of any moderate pragmatism - say, conceptions more or less in accord with the tally earlier provided. So that if Brandom cannot rely on his reading of Wittgenstein to buttress the genuinely pragmatist character of his inferentialism, which in fact relies almost entirely on extending the (already) settled work of algorithmically regularized inference-forms drawn from the special vocabularies of formal semantics (introduced in Between Saying and Doing), then it should become quite clear that Brandom's misreading of Wittgenstein (if confirmed) might well signify that he's made no use of any sustained analysis (Wittgensteinian or not) of the actual and possible ways in which inferential linkages in language-games or fragments of ordinary natural-language discourse are processed and discerned or reasonably imputed.

But if so, then I, for one, cannot see the force of claiming that Brandom's own model of a 'semantic logicism' is a full-bodied form of pragmatism. ${ }^{33}$ It's entirely possible that Brandom means little more, by "pragmatic," than that, in pertinent contexts, we are entitled to replace the inferentially implicit "content" of what speakers 'do' (verbally and non-verbally) with the appropriately matched 'content' of what, on Brandom's own argument, we say speakers could then 'say,' preserving implicit inferential intentions (or intended content) ranging over expressive and behavioral episodes. But strategies of these sorts have surely not yet earned the right to claim a privileged approach to the analysis of the 'logical' life of natural-language discourse! Yet that is precisely what Wittgenstein's exercises (in Investigations) put at mortal risk. That is the key to the tempting suggestion that Wittgenstein may have been a pragmatist after all. (In effect: distancing himself as far as possible from what, as it turns out, Brandom actually calls Frege's 'pragmatism.') Furthermore, to have stalemated the extreme uses of deflationism and naturalism (more strenuously championed by Price than by Brandom) is to deprive Brandom of the other principal dialectical resources he himself invokes in his attempt to lay a proper ground for inferentialism. But then, as it turns out, Brandom's mistake in pressing a deflationist reading of 'true' unexpectedly anticipates the import of his misreading of Wittgenstein.

\section{BIBLIOGRAPHY}

BLACKBURN Simon, (1993), Essays in Quasi-Realism, New York, Oxford University Press.

BRANDOM R. B., (2008), Between Saying and Doing. Towards an Analytic Pragmatism, Oxford University Press.

BRANDOM R. B., (2009), Reason in Philosophy: Animating Ideas, Cambridge, Harvard University Press. BRANDOM R. B., (2011), Perspectives on Pragmatism: Classical, Recent and Contemporary, Cambridge, Harvard University Press.

DENNETT D. C., (1991), Consciousness Explained, Boston, Little-Brown. 
Dummetт Michael, (1981), The Logical Basis of Mataphysics, Cambridge, Harvard University Press. GROVER D., CAMP J., \& N. BeLnAP, (1975), “A Prosentential Theory of Truth,” Philosophical Studies 27. MCDOWELL J., (2000), “Toward Rehabilitating Objectivity,” in R. Brandom (ed.), Rorty and His Critics, Oxford, Blackwell.

MARGolis J., (2012), Pragmatism Ascendent: A Yard of Narrative, An Ounce of Prophecy, Stanford, Stanford University Press.

PRICE Huw, (2011), Naturalism without Mirrors, New York, Oxford University Press.

PUTNAM Hilary, (1994), "Sense, Nonsense, and the Senses: An Inquiry into the Powers of the Human Mind," Journal of Philosophy 91, 495-517.

PUTNAm Hilary, (1995), “Was Wittgenstein a Pragmatist?," in Hilary Putnam, Pragmatism: An Open Question, Oxford, Blackwell, 27.

PUTNAM Hilary, (1995), Pragmatism: An Open Question, Oxford, Blackwell.

PUTNAm Hilary, (2000), “Richard Rorty on Reality and Justification," in R. Brandom (ed.), Rorty and His Critics, Oxford, Blackwell.

RORTY Richard, (1979), Philosophy and the Mirror of Nature, Princeton, Princeton University Press.

RORTY Richard, (1989), Contingency, Irony, and Solidarity, Cambridge, Cambridge University Press.

RORTY Richard, (1991), Objectivity, Relativism and Truth: Philosophical Papers I, Cambridge,

Cambridge University Press.

RORTY Richard, (2000), "Response to Hilary Putnam," in R. Brandom (ed.), Rorty and His Critics, Oxford, Blackwell.

WHiting Daniel, (2009), “Between Old and New: Brandom's Analytic Pragmatism,” International Journal of Philosophical Studies, (4) 17.

\section{NOTES}

1. See Hilary Putnam, “Was Wittgenstein a Pragmatist?," (1995: 27).

2. Putnam (1995: xi).

3. Putnam (1995: 27).

4. Richard Rorty (1979: 5, 7).

5. Putnam (1995: 34-6).

6. Rorty (1979: 373). Rorty claims to be an opponent of analytic scientism, but his proclivities remain eliminativist, as they've been for a very long time. Compare Hilary Putnam (2000), "Richard Rorty on Reality and Justification"; and Rorty's "Response to Hilary Putnam," in the same volume. Putnam may have made too much of some lines in Richard Rorty, Contingency, Irony, and Solidarity, (1989: 6-7) (within the whole of the essay, "The Contingency of Language"). The simple fact is that Rorty is often indifferent to seeming paradox and inconsistency - and, very possibly, at times, to stubborn inconsistency (for example, his own).

7. I provide the details of such a form of realism (among the pragmatists) in my Pragmatism Ascendent: A Yard of Narrative, An Ounce of Prophecy, (2012).

8. John McDowell's "Toward Rehabilitating Objectivity," (2000), notes that Rorty (1991), approves of Putnam's having argued that "notions like 'reference' - semantical notions which relate language to nonlanguage - are internal to our overall view of the world"; that "From the 
standpoint of the representionalist, the fact that notions like representation, reference, and truth are deployed in ways that are internal to a language or a theory is no reason to deny them" (6; cited at 114 by McDowell). I'd forgotten this nice piece of civility. But I think I may say that, here, both Rorty and Putnam are clearly pragmatists, but neither was able to hold the line: not Rorty in what I've already cited from The Mirror of Nature, and not Putnam, in his Dewey Lectures, (1994: 495-517).

9. I take this to be the 'conserving,' the deliberately 'conservative,' import of Brandom's entire program - opposed, if I may say so, to the radical economies of Rorty's postmodern pragmatism and, as we shall see, to the very differently motivated 'semantic minimalism' of the kind of naturalism favored by Huw Price, who is otherwise an ally of Brandom's. Brandom makes it clear at the very start of his account that his formulation (what he calls 'semantic logicism') is meant to be hospitable to all kinds of ways of treating 'semantic relations between vocabularies' (serving inferentialism's program): "analysis, definition, paraphrase, translation, reduction of different sorts, truth-making, and various kinds of supervenience" - where "it is characteristic of classical analytic philosophy that logical vocabulary is accorded a privileged role in specifying these semantic relations" (Between Saying and Doing, 2). I make the worry explicit because Rorty seems to be a bit shocked by Brandom's effort (which is odd) and Price seems baffled by Brandom's way of proceeding (which might well be puzzling to an extreme deflationist).

10. Brandom (2008: 1).

11. Two short pieces come to mind that have helped me in reviewing these matters. The first is Brandom's "Response to John McDowell," addressed to John McDowell, "Comment on Lecture One" (of Between Saying and Doing), one of a series of instructive papers by different hands (and responses to each by Brandom), collected in Philosophical Topics, 36 (2), 2008. Here, Brandom confirms his intent to bring analytic philosophy and pragmatism together in order to launch his 'analytic pragmatism' (135). But he also explains the sense in which he's not wedded to any particular 'paradigmatic core program' (empiricism, naturalism, artificial intelligence, functionalism, or the like) (135). He's prepared to shift from one to another, quite freely, wherever any such option proves to be particularly helpful.

The other piece is a trim Critical Notice of Brandom's book: Daniel Whiting (2009). Whiting expresses doubts about the novelty of Brandom's general approach: "Both its proximity to pragmatism and, especially, its distance from traditional analytic philosophy (as he characterizes both) seem overstated. VV-sufficiency and -necessity claims [that is, claims involving matched target and base vocabularies] are the traditional fodder of analytic philosophy (as Brandom describes it) and can be arrived at without the apparatus of MURs [that is, 'meaning-use relations']" (606). Compare the text of Ch. 1, Between Saying and Doing. Whiting's doubts also suggest considering anticipations in (say) Dewey's Logic and Peirce's pragmatic 'maxim' (in "How to Make Our Ideas Clear"). I must thank my assistant, Phillip Honenberger for drawing my attention to, and making available, these (and related) materials.

12. Compare Michael Dummett (1981, Introduction).

13. Brandom (2008: 202).

14. See Huw Price (2011: 308-9).

15. See Price (2011: 186).

16. See Daniel C. Dennett 1991.

17. Price (2011: 137).

18. Price (2011: 136).

19. Price (2011: 147). On the 'Carnap Thesi,' see 136-7.

20. Price (2011: 30-2, 185-7).

21. Price (2011: 31). That Price entertains the idea at all is already completely incompatible with any viable form of pragmatism - hence, on my argument, any defensible form of naturalism. 
22. See Price (2011: xi, 319-21). Compare Robert B. Brandom (2011: 140-1). See, also, Simon Blackburn (1993, Ch. 1), which colors the exchange between Price and Brandom.

23. See Robert B. Brandom (2009: 163-5). Brandom cites as the original source of the idea, D. Grover, J. Camp, \& N. Belnap (1975), which I have not read.

24. See Robert B. Brandom, "Why Truth is Not Important in Philosophy," (2009: 159).

25. Brandom (2009: 158); but compare the rest of the chapter.

26. Price (2011: 318); compare Brandom (2008: 177-8).

27. Price (2011: 186).

28. Price (2011: 186).

29. Price (2011: 185-7).

30. Price (2011: 116-7; see, also, 115).

31. Paul Horwich, "The Minimalist Conception of Truth," slightly revised, abstracted from his Truth, 2nd. ed., Oxford, Oxford University Press, 1998, in Truth, S. Blackburn and K. Simmons (eds.), Oxford, Oxford University Press, 1999, 240.

32. Regarding the first two themes, see, further, Brandom (2011, Introduction and Ch. 7).

33. See Brandom (2008: 48-54).

\section{ABSTRACTS}

The paper notices that different readings have been provided as for the connections between Wittgenstein and pragmatism, such as for example H. Putnam's picture as opposed to R. Rorty's description that packages Wittgenstein and Dewey together as 'postmodern' pragmatists. Joseph Margolis tries to broaden the discussion by including an examination of Wilfrid Sellars, Gottlob Frege, Robert Brandom, and Huw Price. His aim it to review the newer challenges of naturalism and deflationism, which, by their own instruction, should bring us to the decisive contest between the 'pragmatism' of the Investigations and that of Brandom's Between Saying and Doing. The larger purpose of this exercise is to assess pragmatism's best prospects currently, in meeting the gathering challenges of the day.

\section{AUTHOR}

\section{JOSEPH MARGOLIS}

Temple University

josephmargolis455[at]hotmail.com 